\title{
Corporate Governance Mechanisms and Corporate Social Responsibility (CSR) in Kuwaiti Listed Firms
}

\author{
Mejbel Al-Saidi ${ }^{1}$ \\ ${ }^{1}$ Associate professor, Accounting Department, PAAET, Kuwait \\ Correspondence: Mejbel Al-Saidi. E-mail: AL-SaidiMTMT@hotmail.com
}

Received: March 23, 2020

Accepted: June 23, $2020 \quad$ Online Published: July 22, 2020

doi:10.5539/ass.v16n8p10

URL: https://doi.org/10.5539/ass.v16n8p10

\begin{abstract}
Firms must maintain a balance between their performance and corporate social responsibility (CSR). This study examines the relationship between corporate governance mechanisms and the CSR of firms listed on the Kuwait Stock Exchange (KSE) within the framework of agency theory. Using a sample of 86 firms in 2019, this study explored five corporate governance mechanisms (i.e., ownership concentration by large shareholders, ownership concentration by government, board size, board independence, and family directors) and five control variables (i.e., debt, firm size, firm age, profitability, and industry type). The study used the index checklist to measure CSR and found that ownership concentration by large shareholders, ownership concentration by government, and board size affect a firm's social responsibility while other variables have no impact. This study was the first to examine the impact of corporate governance mechanisms on corporate social responsibility in Kuwait after introducing the new corporate governance rules, and the findings will help Kuwait's government, firms, and investors evaluate the current rules and improve CSR requirements.
\end{abstract}

Keywords: Corporate Social Responsibility (CSR), corporate governance, Kuwait

\section{Introduction}

Corporate governance, which is the process of controlling and monitoring management, introduces many mechanisms to reduce conflict occurring between managers and shareholders or among shareholders. After the 2001 recession and the ensuing problems in Asia, many countries around the world built their own corporate governance system using mechanisms they considered to be effective and useful in not only improving firm performance, but also helping listed firms fulfill their social obligation toward society and the environment. One of the most important goals for corporate governance is corporate social responsibility (CSR), which is used to help shareholders and stakeholders ensure that their firms maintain a balance between human rights and environmental stewardship, in addition to firm performance and value.

According to the majority of previous studies discussed herein, the concept of CSR first emerged in the 1950s, focusing on the obligations of businessmen who owned the firms until modern firms were developed, giving shareholders the rights to own shares. In the 1960s and 1970s, this concept was further developed to include employees' rights, environmental issues, and consumer protections. Carroll (1979) defined CSR as a model consisting of four types of corporate responsibilities and social issues. In the 1980s and 1990s, Wood (1991) expanded previous CSR definitions to include three additional principles of corporate behaviors: responsibility, managerial discretion, and legitimacy. Hopkins (2005) subsequently included stakeholders, so CSR incorporated all information related to stakeholders and the environment. Blowfield and Murray (2008) further argued that CSR includes business ethics, legal compliance, society investment, philanthropy, environment, sustainability, animal and human rights, market relations, and corporate governance.

Kuwait had no corporate governance rules until mid-2016. The government introduced rules in 2012 and established the Capital Market Authority (CMA) in 2013, but did not adopt the regulations until June 2016, following three years of discussions with the National Assembly. These corporate governance regulations are divided into 11 rules that include the role of the board of directors, disclosures, and large shareholders. Rule number 11 discusses the importance of social responsibility and how Kuwaiti listed firms can engage in it. This rule encourages listed firms to protect the environment, employees' rights, and society and required them to dedicate a percentage from their net income for social services and protects. In addition, listed firms must build policy that ensures a balance between the firm's goals and society goals as well as developed policies and 
programs, thereby ensuring the listed firms increase their social contributions.

This study examines the impact of five corporate governance mechanisms on CSR and investigates whether the level of CSR affected corporate governance once Kuwait's listed firms adopted the new corporate governance rules. This study differs from previous studies in three aspects. First, all previous studies in Kuwait that examined CSR were conducted in the absence of corporate governance rules. Al-Hajri and Al-Enezi (2019) studied CSR in a sample of 81 listed firms from 2011 to 2012 and found that the mean value of CSR is 0.19 while Al-Shammari (2012) used a sample of 40 listed firms in 2010 and found the mean value of CSR to be 0.18 . Second, unlike previous studies, this study examined CSR in a developing country using five corporate governance mechanisms. To the best of the author's knowledge, this research is one of a few studies to analyze CSR using such a number of variables. Third, in examining current CSR, this study helps the government and regulators develop their regulations, thereby improving our understanding of the factors that impact CSR. It also improves the successful implementation of corporate governance rules and provides better information for shareholders, investors, and boards, leading to competitive and well-organized listed firms.

To achieve these goals, the rest of this study is organized as follows. Section 2 presents the literature review and hypothesis development. Section 3 presents the methodology, and Section 4 presents the results and discussion. Conclusions are offered in the final section.

\section{Literature Review and Hypotheses}

\subsection{Theoretical Framework}

Carroll (1979) identified four dimensions that must be considered in the model of social responsibility: economic, legal, ethical, and philanthropic. The economic dimension includes salaries, employees, job creation, services, and improvements to firm value while the legal dimension relates to regulations; the ethical dimension encompasses moral issues, and the philanthropic dimension relates to social contribution projects and programs. El-Kassar et al. (2017, p. 219) studied corporate governance and CSR in Lebanon, concluding that "CSR began in developed countries, mainly in large corporations like Microsoft, Walt Disney, and Google and many others. Nowadays, it is becoming a major [consideration] of institutions in all countries." Amaladoss and Manohar (2013) argued that CSR in developing countries is related more to charity and community, unlike in developed countries, where it is more related to the environment, ethics, and stakeholders' issues. Wood (1991) found that no single CSR principle was true for all firms as the principles differ from firm to firm. Studies from the 1970s and 1980s examined the CSR concept or tried to link CSR to profitability or performance. However, El-Kassar et al. (2017) and Jamali and Mirshak (2007) argued that, after the financial crises and globalization, investors around the world started to ask about social and environmental factors, as they believed that good corporate governance led to a high level of social responsibility.

The Cadbury report (1992) defined corporate governance as "the system by which companies are directed and controlled". Agency theory is widely used in the literature to explain the corporate governance mechanisms. Thus, to be consistent with the majority of previous studies, this study examined this relationship in the framework of agency theory. Agency theory argues that the owners (principal) and manager (agent) have a conflicting relationship (Jensen \& Meckling, 1976). Consistent with this view, La Porta et al. (1999) found another conflict between large and small shareholders and between large shareholders and creditors. Both of these studies argued that reducing these conflicts leads to better firm value and better monitoring and controlling, thereby resulting in improved quality of CSR or-alternatively - the problem of asymmetry information, which negatively affects firm performance. In this context, several previous studies have suggested various mechanisms to deal with this conflict, such as ownership structure, board of directors, and financial policies. This study used five governance mechanisms: ownership concentration by large shareholders, ownership concentration by government, board size, board independence, and family directors. Table 1 lists the empirical studies that examined the impact of these five mechanisms on CSR, and the next subsection develops the hypotheses tested in this study.

\subsection{Hypothesis Development}

Ownership structure has been used as an important mechanism in explaining CSR variations. Khan et al. (2012), Reverte (2009), and Lau et al. (2016) examined the impact of ownership concentration by large shareholders on CSR in different countries, arguing that this variable leads to differences in the level of CSR. Applying agency theory, firms with more ownership concentration are expected to disclose less information in their annual reports - known as the expropriation hypothesis. It occurs more in developing countries, where there is weak shareholder protection (La Porta et al., 1999). Large shareholders may reduce the level of CSR and work for their benefits only, thereby increasing the agency conflict among shareholders and between large shareholders 
and creditors.

Empirical studies exploring the relationship between CSR activities and ownership structure are mixed. Isa and Muhammed (2015) reported no impact of ownership concentration by large shareholders on CSR in Nigeria, whereas Abu-Sufian and Zahan (2013), Hu et al. (2016), Ali and Atan (2013), Said et al. (2009), and Soliman and El-Din (2012) reported a positive impact of ownership concentration by large shareholders on CSR activities. Meanwhile, Reverte (2009), Lau et al. (2016), and Khan et al. (2012) found that ownership concentration negatively impacts CSR activities. Meanwhile, some studies used ownership concentration by the government as a variable and found interesting results. For example, Lau et al. (2016), Habbash (2016), Oh et al. (2011), Esa and Zahari (2016), Said et al. (2009), and Ghazali (2007) found that government ownership positively affects CSR activities. They argued that the government faced more pressure from society to increase social and community information. Such differences in results are logical given the different ownership structures governance rules around the world.

In Kuwait, the current rules require all listed firms to publish their ownership shares when they exceed 5 percent of total outstanding shares. According to Al-Shammari (2007) and Al-Saidi (2013), there are three major shareholders in Kuwait: institutions, the government, and families (individuals). These groups are insiders because they have strong access to the firms' information through their representatives in the board of directors; thus, they may influence the level and quality of CSR. Consistent with agency theory, firms with more ownership concentration have less motivation to publish CSR activities than firms with less ownership concentration, which leads to the first two hypotheses:

H1: Ownership concentration negatively impacts CSR activities.

H2: Ownership concentration by the government negatively impacts CSR activities.

Table 1. Studies Examining CSR and Governance Mechanisms

\begin{tabular}{|c|c|c|c|}
\hline Authors & Country & Year & Impact of CSR \\
\hline Habbash (2016) & Saudi Arabia & $2007-2011$ & $\mathrm{GOC}(+), \mathrm{FD}(+)$ \\
\hline Abu-Sufian and Zahan (2013) & Bangladesh & 2010 & $\mathrm{BS}($ non), $\mathrm{OC}(+)$ \\
\hline Wu et al. (2012) & Taiwan & 2007-2009 & $\mathrm{FD}(-)$ \\
\hline Oh et al. (2011) & Korea & 2006 & $\mathrm{GOC}(+)$ \\
\hline Esa and Zahari (2016) & Malaysia & 2006 & $\mathrm{GOC}(+), \mathrm{FD}(+), \mathrm{BS}(+)$ \\
\hline Hu et al. (2016) & China & 2010 & $\mathrm{OC}(+)$ \\
\hline Naseem et al. (2017) & Pakistan & 2009-2015 & $\mathrm{BS}(+), \mathrm{BI}(+)$ \\
\hline Isa and Muhammed (2015) & Nigeria & $2014 / 2015$ & $\mathrm{BS}(+), \mathrm{BI}(+), \mathrm{OC}($ non $)$ \\
\hline Lamb et al. (2017) & USA & 1994-2006 & $\mathrm{FD}($ non $)$ \\
\hline Dias et al. (2017) & Portugal & 2011 & $\mathrm{BS}(+)$ \\
\hline Arani (2016) & Iran & 2009-2014 & $\mathrm{BS}(+), \mathrm{BI}(+)$ \\
\hline Ali and Atan (2013) & Malaysia & 2009 & $\mathrm{OC}(+), \mathrm{BS}(+), \mathrm{BI}(+)$ \\
\hline Said et al. (2009) & Malaysia & 2006 & $\mathrm{OC}(+), \mathrm{GOC}(+), \mathrm{BS}(+), \mathrm{BI}($ non $)$ \\
\hline Liu et al (2017) & USA & 2003-2010 & $\mathrm{FD}(+)$ \\
\hline Beji et al. (2020) & France & 2003-2016 & $\mathrm{BI}(+), \mathrm{BS}(+)$ \\
\hline Pham and Tran (2019) & 20 countries & $2005-2011$ & BI(non) \\
\hline Zhuang et al. (2018) & China & 2008-2016 & $\mathrm{BI}(-), \mathrm{BS}(+)$ \\
\hline Khan et al. (2012) & Malaysia & 2005-2007 & $\mathrm{OC}(-), \mathrm{BI}(+)$ \\
\hline Rees and Rodionova (2015) & 46 countries & 2002-2012 & $\mathrm{FD}(-)$ \\
\hline Soliman and El-Din (2012) & Egypt & 2007-2009 & $\mathrm{OC}(+)$ \\
\hline Ghazali (2007) & Malaysia & 2001 & $\mathrm{GOC}(+)$ \\
\hline Reverte (2009) & Spain & 2005-2006 & OC(-) \\
\hline Lau et al. (2016) & China & $2010-2011$ & $\mathrm{GOC}(+), \mathrm{BS}(+), \mathrm{OC}(-)$ \\
\hline Mousa et al. (2018) & Gulf Cooperation Council & 2016 & $\mathrm{BS}(+), \mathrm{BI}(-)$ \\
\hline Jizi et al. (2014) & USA & 2009-2011 & $\mathrm{BS}(+), \mathrm{BI}(+)$ \\
\hline Abu-Qa'dan and Swuaidan (2019) & Jordan & 2013-2015 & $\mathrm{BS}(+), \mathrm{BI}(-)$ \\
\hline
\end{tabular}

Notes: Ownership concentration by large shareholders (block holders) $=$ OC, government ownership concentration $=$ GOC, board size $=$ BS, board independence $=$ BI, family director $=$ FD (studies measured this variable using three measures: ownership, directors, and managers). 
In term of board size, with the exception of one study (Abu-Sufian \& Zahan, 2013), all previous studies discussed herein found a positive relationship between board size and CSR activities (Abu-Qa'dan \& Swuaidan, 2019; Ali \& Atan, 2013; Arani, 2016; Beji et al., 2020; Dias et al., 2017; Esa \& Zahari, 2016; Isa \& Muhammed, 2015; Jizi et al., 2014; Lau et al., 2016; Mousa et al., 2018; Naseem et al., 2017; Said et al., 2009; Zhuang et al., 2018), implying that big board size provides shareholders and stakeholders with high CSR activities. However, this study still supports the argument of agency theory that a small number of board directors has a positive impact on firms' controlling and monitoring (Jensen \& Meckling, 1976; Yermack, 1996). Therefore, this study argued that a smaller board size is more likely to provide more information about CSR activities in their annual reports to attract more investors and satisfy the society's and stakeholders' needs. Board size's impact on CSR varies across countries, with a small board size being good for some firms but bad for others. In the case of Kuwait, the current rules set the minimum number of directors at five for each firm, but identify no maximum number. Based on agency theory, board size is expected to have a negative impact on CSR in Kuwait. Thus, the third hypothesis is:

\section{H3: Board size negatively impacts CSR activities.}

Similar to the previous hypothesis, agency theory asserts that board independence positively impacts firms and, thus, CSR activities because board independence improves firm value and provides good monitoring for managers and large shareholders (Jensen \& Meckling, 1976). Board independence refers to the number of non-executive directors compared to total directors. More non-executive directors may improve the board's effectiveness and help reduce agency conflict inside the meeting room while controlling managers' opportunistic behaviors (Jensen \& Meckling, 1976), thereby increasing the level of disclosure about CSR activities. However, empirical studies have produced mixed results regarding the impact of board independence on CSR activities. For example, Naseem et al. (2017), Isa and Muhammed (2015), Arani (2016), Ali and Atan (2013), Beji et al. (2020), Jizi et al. (2014), and Khan et al. (2012) argued that board independence can help firms disclose more CSR activities to outside investors and improve the monitoring of information quality; thus, board independence leads to a higher level of CSR activities. However, other studies, such as Said et al. (2009), studied the situation in Malaysia and found no significant relationship between the two variables. Pham and Tran (2019) found similar results in their study of the same issue in 20 countries around the world. Meanwhile, Abu-Qa'dan and Swuaidan (2019), Zhuang et al. (2018), and Mousa et al. (2018) found that board independence reduces the level of CSR activities because in some countries directors are not truly independent; they are appointed by large shareholders and look to these shareholders' interests only. In Kuwait, the new rules require listed firms to have at least one independent director on their board, but no more than $50 \%$ of all directors. This study predicts that a board with more independent directors will be more sensitive to the stakeholders' needs and will show more concern about CSR activities. Thus, independent directors encourage firms to disclose more information about CSR activities and assure stakeholders that they are acting in their interests and reducing agency conflicts. Therefore, the fourth hypothesis is:

\section{H4: Board independence positively impacts CSR activities.}

For the last hypothesis, agency theory argues that family directors can reduce conflicts of interest within firms because the owners and directors are usually the same person (Jensen \& Meckling, 1976). Consistent with this view, James (1999) argued that families offer many advantages, such as trust, long relationships, and altruism, that lead to strong commitment to the firms. However, empirical studies have produced mixed results. For example, Habbash (2016), Esa and Zahari (2016), and Liu et al. (2017) examined the impact of family directors on CSR activities and a found positive relationship. They explained that families disclose more CSR activities because they care about their names and reputations. However, some studies have asserted that family firms are controlled by large families' shareholders; they act for their benefit only and thus disclose fewer CSR activities (Rees \& Rodionova, 2015; Wu et al., 2012). Meanwhile, Lamb et al. (2017) found no significant relationship between family directors and information on CSR activities. Al-Shammari (2007) found that Kuwaiti families have strong power and influence; they also care about their names. Thus, consistent with agency theory and with families' advantages, this study assumed that family directors are more effective in monitoring and controlling and, consequently, are expected to disclose more CSR activities. The last hypothesis is:

\section{H5: Family directors positively impact CSR activities.}

\section{Study Methodology}

As the literature review indicated, several variables that influence the relationship between corporate governance mechanisms and CSR remain to be explored. To bridge this gap, the study examines the impact of five governance mechanisms and five control variables on CSR. Figure 1 presents the research framework model of 
this study. This study used 173 listed firms in 2019 (67 financial firms and 106 non-financial firms). However, after excluding the financial firms and some non-financial firms because they did not disclose financial data for 2019 at the time of writing this study, our final sample was 86 firms. Data were collected from firms' annual reports available on the KSE website.

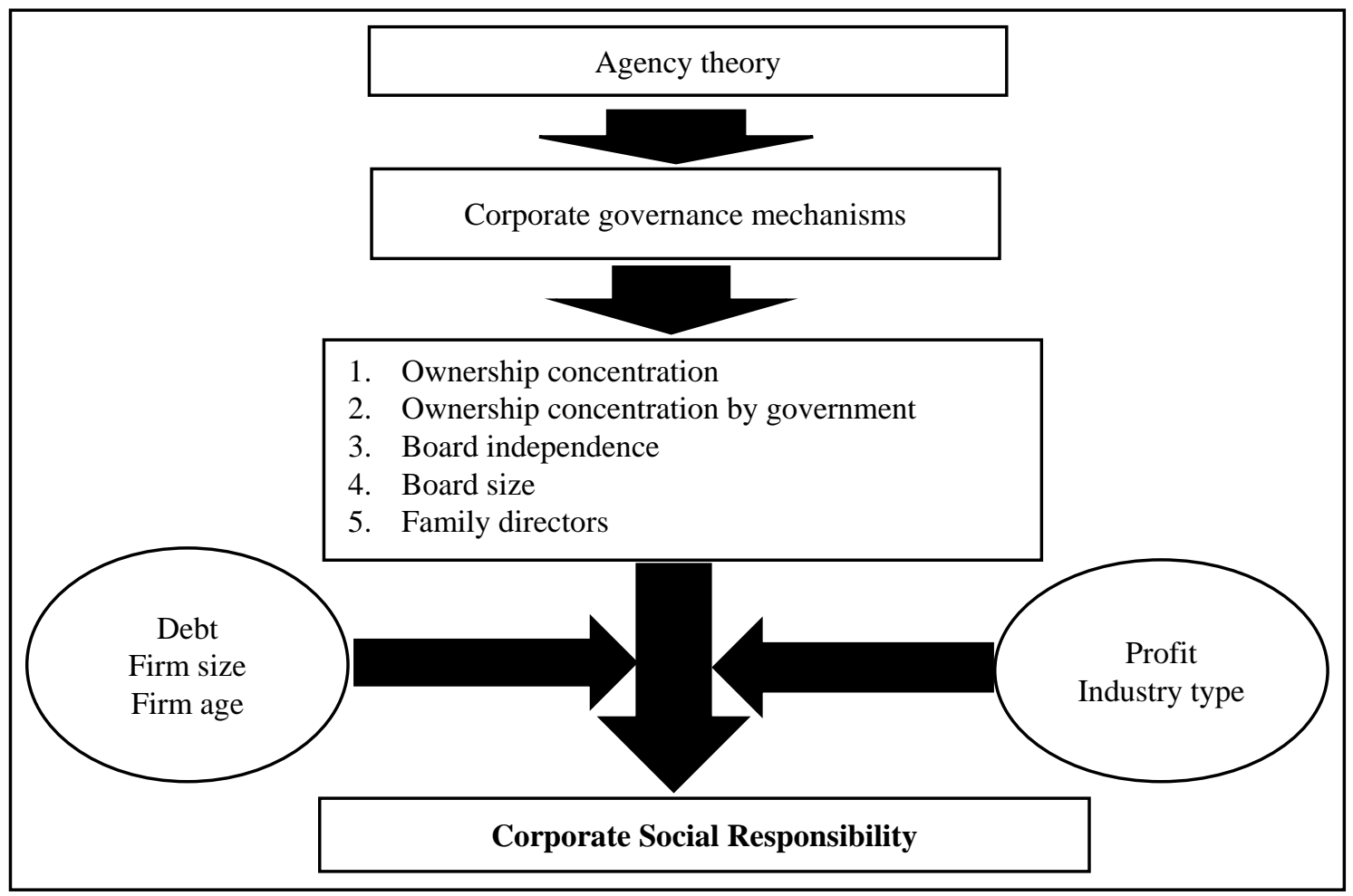

Figure 1. Research framework model

Social responsibility information and activities were hand-collected, and the CSR disclosure index represents the dependent variable in the study. ${ }^{1}$ The CSR disclosure index was created based on previous studies (see Table 1), and the study used a checklist of 40 items covering 5 themes: CSR policy ( 7 items), strategy of employment (11 items), environment (6 items), customers and suppliers ( 9 items), and social involvement ( 7 items). The firms were scored as 1 if they disclosed an item on the checklist and 0 if not disclosed; the scores were totaled and then divided by 40 to obtain the CSR index for each firm. Furthermore, the study used five independent variables (i.e., ownership concentration by large shareholders, ownership concentration by government, board size, board independence, and family directors) and five control variables (i.e., debt, firm size, firm age, profitability, and industry type). Table 2 presents the study variables. An OLS regression analysis was used to examine the impact of corporate governance mechanisms on CSR. The regression model employed is as follows:

$$
\mathrm{CSR}=\alpha+\beta 1 \mathrm{OC}++\beta 2 \mathrm{GOC}+\beta 3 \mathrm{BS}+\beta 4 \mathrm{BI}+\beta 5 \mathrm{FD}+\beta 6 \mathrm{DT}+\beta 7 \mathrm{FS}+\beta 8 \mathrm{FA}+\beta 9 \mathrm{PR}+\beta 10 \mathrm{IT}+\varepsilon
$$

Table 2. Study Variables

\begin{tabular}{lc}
\hline \multicolumn{1}{c}{ Variables } & Definitions \\
\hline Corporate social responsibility (CSR) index & Dependent variable \\
\hline & Index based on 40 items (five themes) \\
\hline Ownership concentration (OC) & Total ownership concentration by large shareholders \\
Government ownership concentration (GOC) & Total ownership concentration by government \\
Board size (BS) & Total number of directors on the board \\
Board independence (BI) & Proportion of independent directors on the board \\
Family directors (FD) & Percentage of family directors on the board \\
\hline
\end{tabular}

${ }^{1}$ The CSR index is not included in this study but is available upon request. 


\begin{tabular}{ll}
\hline & Control variables \\
\hline Debt (DT) & Debt ratio (total liabilities $\div$ total assets) \\
Firm size (FS) & Natural log of total assets \\
Firm age (FA) & Natural log of listing year \\
Profitability (PR) & Market value of firm + total debt $\div$ total assets \\
Industry type (IT) & Industry classification in Kuwait Stock Exchange \\
\hline
\end{tabular}

\section{Results and Discussion}

\subsection{Descriptive Analysis}

As the study used OLS regression, OLS assumptions such as multicollinearity, autocorrelation, homoscedasticity, linearity, and normality were tested, and the regression did not indicate any of these serious problems in the examined model. No multicollinearity problem exists if the relationship among independent variables is less than $80 \%$ (Brooks, 2014). Table 3 indicates that all relationships among variables are less than $80 \%$. Table 4 presents the samples' descriptive statistics. The mean value of CSR in Kuwait is $25 \%$, with a maximum value equal to $45 \%$ and a minimum value equal to $10 \%$. This is more than the results of Al-Hajri and Al-Enezi (2019) and Al-Shammari (2012), who examined CSR in Kuwait, thereby implying Kuwait's new corporate governance rules led to increased CSR. However, the current study's results are much less than those in Mousa et al. (2018), which found the mean value of CSR among GCC countries to be 39\%. Listing firms in Kuwait are highly concentrated, with a mean score of $57 \%$ for ownership concentration and $4.7 \%$ for government ownership. The mean value of board size is about 6.12 , while board independence equals $82 \%$, and family directors in Kuwait equals 23\%. Al-Shammari and Al-Sultan (2009) found ownership concentration by large shareholders equals $55 \%$, board independence equals $82 \%$, and board size equals 6.39 .

Table 3. Pearson Correlation Coefficients Matrix for the Study's Variables

\begin{tabular}{|c|c|c|c|c|c|c|c|c|c|c|}
\hline & CSR & $\mathrm{OC}$ & GCO & BS & BI & FD & DT & FS & FA & PR \\
\hline CSR & 1 & & & & & & & & & \\
\hline $\mathrm{OC}$ & $-0.2 * *$ & 1 & & & & & & & & \\
\hline GOC & $0.28 * *$ & 0.09 & 1 & & & & & & & \\
\hline BS & $0.40^{* *}$ & -0.027 & $0.29 * *$ & 1 & & & & & & \\
\hline BI & -0.07 & 0.096 & -0.034 & 0.033 & 1 & & & & & \\
\hline FD & 0.113 & 0.085 & -0.067 & 0.025 & 0.065 & 1 & & & & \\
\hline DT & 0.06 & 0.105 & -0.054 & 0.110 & 0.032 & 0.186 & 1 & & & \\
\hline FS & $0.21 *$ & 0.025 & 0.106 & $0.402 * *$ & 0.041 & 0.142 & $0.54 * *$ & 1 & & \\
\hline FA & 0.175 & -0.007 & 0.121 & $0.227^{*}$ & -0.02 & 0.014 & 0.11 & $0.20 * *$ & 1 & \\
\hline PR & -0.12 & $0.211^{*}$ & 0.005 & 0.093 & 0.002 & -0.10 & 0.080 & 0.146 & -0.08 & 1 \\
\hline
\end{tabular}

Notes: $* * * * *$, and $*$ significant at the 0.01 .0 .05 , and 0.10 levels, respectively (two-tailed). For definitions of the variables, see Table 2.

Table 4. Descriptive Statistics for All Study Variables

\begin{tabular}{cccccc}
\hline Variables & Sample & Mean & SD & Maximum & Minimum \\
\hline CSR & 86 & 0.25 & 0.10 & 0.45 & 0.10 \\
OC & 86 & 0.57 & 0.22 & 0.96 & 0 \\
GOC & 86 & 0.047 & 0.112 & 0.69 & 0 \\
BS & 86 & 6.12 & 1.36 & 10 & 4 \\
BI & 86 & 0.82 & 0.17 & 1 & 0.21 \\
FD & 86 & 0.23 & 0.23 & 1 & 0 \\
DT & 86 & 0.401 & 0.22 & 0.99 & 0.01 \\
FS(log) & 86 & 4.9 & 0.58 & 6.65 & 3.16 \\
FA(log) & 86 & 1.2 & 0.19 & 1.59 & 0.30 \\
PR & 86 & 0.96 & 0.80 & 6.34 & 0.20 \\
\hline
\end{tabular}

Notes: For definitions of the variables, see Table 2 


\subsection{Results and Discussion}

Table 5 presents OLS regressions for the impact of corporate governance mechanisms on CSR in non-financial listed firms in KSE. The model, which incorporates five independent variables and five control variables, explained 32\% of the variations in CSR disclosure in Kuwait (Adjusted R-squared $=32 \%$ ). In terms of ownership concentration by large shareholders, this finding is consistent with the agency theory view and many previous studies (Khan et al., 2012; Lau et al., 2016; Reverte, 2009), implying that ownership concentration by large shareholders in Kuwait does not lead to more CSR activities. However, other studies (Abu-Sufian \& Zahan, 2013; Ali \& Atan, 2013; Hu et al., 2016; Said et al., 2009; Soliman \& El-Din, 2012) found that ownership concentration by large shareholders enhanced information about CSR activities. The results confirmed that large shareholders are not interested in increasing the level of CSR activities because they face no pressure to meet stakeholders' needs. This study supported the agency theory's argument that agency conflict exists among shareholders and between large shareholders and creditors in developing countries (La Porta et al., 1999). Thus, Hypothesis 1 is supported.

Regarding Hypothesis 2, the regression coefficients of the relationship between ownership concentration by government and CSR suggested that a significant positive relationship exists between the two variables. Thus, Hypothesis 2 is not supported, consistent with the findings from Habbash (2016), Oh et al. (2011), Esa and Zahari (2016), Said et al. (2009), Ghazali (2007), and Lau et al. (2016). Thus, this study found that Kuwait's government plays an important role in improving the extent of CSR information. Government ownership is an important governance tool that encourages firms to comply with the CSR disclosure and protect shareholders' and stakeholders' interests in Kuwait.

Furthermore, a significant positive relationship exists between board size and the level of CSR activities, which confirms previous studies' findings (Ali \& Atan, 2013; Arani, 2016; Beji et al., 2020; Dias et al., 2017; Esa \& Zahari, 2016; Isa \& Muhammed, 2015; Jizi et al., 2014; Lau et al., 2016; Mousa et al., 2018; Naseem et al., 2017; Said et al., 2009; Zhuang et al., 2018) that bigger boards lead to more CSR activities in Kuwait. Firms with big boards may have more diversity and different experiences among directors, leading to efficient monitoring and disclosure of more CSR activities in their annual reports. However, the current results are inconsistent with agency theory and Abu-Sufian and Zahan's (2013) findings. Thus, Hypothesis 3 is not supported either.

Table 5. Ordinary Least Square (OLS) Results

\begin{tabular}{|c|c|c|c|c|}
\hline Variables & Expected relationship & Coefficient & $T$-value & Hypothesis result \\
\hline Constant & & 0.118 & 0.139 & \\
\hline OC & Negative & -0.001 & $-2.946 * *$ & Accepted \\
\hline GOC & Negative & 0.002 & $1.799 *$ & Rejected \\
\hline BS & Negative & 0.025 & $3.290 * * *$ & Rejected \\
\hline BI & Positive & -0.028 & -0.502 & Rejected \\
\hline FD & Positive & 0.057 & 1.375 & Rejected \\
\hline DT & & 0.028 & 0.586 & \\
\hline FS & & 0.033 & $1.701^{*}$ & \\
\hline FA & & 0.038 & $1.811^{*}$ & \\
\hline PR & & -0.001 & -0.051 & \\
\hline IT1 (Oil and gas) & & -0.116 & -0.959 & \\
\hline IT2 (Basic material) & & -0.047 & -0.371 & \\
\hline IT3 (Industrial) & & -0.004 & -0.035 & \\
\hline IT4 (Consumer goods) & & -0.071 & -0.629 & \\
\hline IT5 (Health care) & & -0.098 & -0.748 & \\
\hline IT6 (Consumer services) & & -0.015 & -0.131 & \\
\hline IT7 (Telecommunications) & & -0.093 & -0.766 & \\
\hline IT8 (Real estate) & & -0.006 & -0.052 & \\
\hline$R^{2}=0.438$ & $\operatorname{Adj}-R^{2}=0.32$ & & & Value $=3.708$ \\
\hline
\end{tabular}

Notes: $* * *, * *$, and $*$ significant at the 0.01 .0 .05 , and 0.10 levels, respectively (two-tailed). For definitions of the variables, see Table 2. Industry 9 (technology sector) is excluded. 
Regarding Hypothesis 4, this study's results are inconsistent with agency theory and previous studies (Ali \& Atan, 2013; Arani, 2016; Beji et al., 2020; Isa \& Muhammed, 2015; Jizi et al., 2014; Khan et al., 2012; Lau et al., 2016; Naseem et al., 2017) indicating that board independence leads to more CSR activities and protects shareholders' and stakeholders' interests. Thus, Hypothesis 4 is not supported. These findings are consistent with those of Said et al. (2009), Pham and Tran (2019), Zhuang et al. (2018), and Mousa et al. (2018), who found that board independence does not increase the level of CSR disclosure. Today's Kuwaiti independent directors are not truly independent because they represent large shareholders on the boards. Although new governance rules require listed firms to have at least one independent board member, some firms find having one independent director is not enough to play a significant role in increasing the CSR disclosure and activities.

Finally, regarding Hypothesis 5, the study's findings are consistent with those from several previous studies (Lamb et al., 2017; Rees \& Rodionova, 2015; Wu et al., 2012) that concluded that family directors are not important governance mechanisms and do not lead to a high level of CSR activities. However, Habbash (2016), Esa and Zahari (2016), and Liu et al. (2017) found that family directors positively affect CSR disclosure. Thus, this study does not support agency theory in Kuwait's case, indicating that no relationship exists between family directors and the level of CSR activities. This could be due to two reasons. First, families in Kuwait are large shareholders who can easily access any information through their members on the board; thus, they have no pressure to meet stakeholders' needs. Second, most family directors get their positions through personal relationships and family connections with large shareholders, not important skills such as qualifications, experiences, and education.

Finally, the control variables debt and profitability do not impact CSR activities, but the firm's size and age positively affect CSR activities. Mousa et al. (2018) found that firm size positively impacts CSR because large firms are more confident in disclosing more information about the CSR activities. Soliman and El-Din (2012) also found that both firm size and age positively impact CSR in Egypt. In Kuwait, larger and older firms have more resources to bear the costs of engaging in more social activities, although the industry variable does not impact CSR.

\section{Conclusion}

This study examined whether corporate governance mechanisms affect CSR activities and disclosure in Kuwait using a sample of 86 non-financial listed firms on the KSE in 2019. The results indicated that ownership concentration by large shareholders, ownership concentration by government, and board size were significant factors explaining CSR activities. However, board independence and family directors have no significant impact on CSR activities and disclosures. Moreover, firm size and firm age positively impact CSR activities whereas debt, profitability, and industry type have no impact.

These findings are important for regulators, academics, and researchers in Kuwait seeking to understand the corporate governance mechanism that impacts CSR and how they can develop it. In addition, the findings indicate the importance of CSR activities for academic researchers; the majority of researchers in Kuwait focus on voluntary and obligatory disclosures while giving less attention to CSR activities. However, the study has some limitations - namely, it used a sample of only one year and collected data on CSR items from the annual reports of non-financial listed firms in Kuwait and used the framework of the agency theory. Thus, future studies should use panel data (many years) or a sample of financial firms. They should adopt a different theoretical framework or include other variables that may relate to CSR disclosure (e.g., institution ownership, family ownership, board diversity). Future researchers might also collect disclosures of CSR activities from firms' websites.

\section{References}

Abu-Qa'dan, M., \& Swuaidan, M. (2019). Board composition, ownership structure and corporate social responsibility disclosure: The case of Jordan. Social Responsibility Journal, 15(1), 28-46. https://doi.org/10.1108/SRJ-11-2017-0225

Abu-Sufian, M., \& Zahan, M. (2013). Ownership structure and corporate social responsibility disclosure. International Journal of Economic and Financing Issues, 3(4), 901-909.

Al-Hajri, M., \& Al-Enezi, F. (2019). The association between corporate social responsibility disclosure and accounting-based financial performance: A Kuwaiti evidence. Investment Management and Financial Innovations, 16(1), 1-13. https://doi.org/10.21511/imfi.16(1).2019.01

Ali, M., \& Atan, R. (2013). The relationship between corporate governance and corporate social responsibility disclosure: A case of high Malaysian sustainability companies and global sustainability companies. South 
East Asia Journal of Contemporary Business, Economies and Law, 3(1), 13-39.

Al-Saidi, M. (2013). Ownership concentration and firm performance: the case of Kuwait. Jordan Journal of Business Administration, 9(4), 803-819. https://doi.org/10.12816/0002094

Al-Shammari, B \& Al-Sultan, W. (2009). Corporate governance and corporate performance: Evidence from Kuwait. Corporate Ownership \& Control, 7(1), 334-349. https://doi.org/10.22495/cocv7i1c3p1

Al-Shammari, B. (2012). Corporate governance and Islamic social responsibility disclosure in Kuwait Shariah compliant financial institutions. Studies of Business and Economics, 16(2), 5-35. https://doi.org/10.29117/sbe.2012.0068

Amaladoss, M., \& Manohar, H. (2013). Communicating corporate social responsibility-A case of CSR communication in emerging economics. Corporate Social Responsibility and Environmental Management, 20(2), 65-80. https://doi.org/10.1002/csr.287

Arani, M. (2016). The effects of corporate governance mechanisms on social responsibility disclosure. Mediterranean Journal of Social Sciences, 7(4), 139-146.

Beji, R., Yousfi, O., \& Loukil, N. (2020). Diversity and corporate social responsibility: Empirical evidence from France. Journal of Business Ethics, 0, 1-23. https://doi.org/10.1007/s10551-020-04522-4

Blowfield, M., \& Murray, A. (2008). Corporate responsibility. Oxford University.

Brooks, C. (2014). Introductory econometrics for finance. Cambridge University Press. https://doi.org/10.1017/CBO9781139540872

Cadbury Committee. (1992). Report of the Committee on the Financial Aspects of Corporate Governance. London, UK: Gee Publishing Ltd

Carroll, A. (1979). A three-dimensional conceptual model of corporate performance. Corporate Governance of Management Review, 497-505. https://doi.org/10.5465/amr.1979.4498296

Dias, A., Rodrigues, L., \& Craig, R. (2017). Corporate governance effects on social responsibility disclosure. Australasian Accounting, Business and Finance Journal, 11(2), 3-22. https://doi.org/10.14453/aabfj.v11i2.2

El-Kassar, A., Elgammal, W., \& Fahed-Sreih, J. (2017). Engagement of family members, corporate governance and social responsibility in family-owned enterprises. Journal of Organizational Change Management, 31(1), 215-229. https://doi.org/10.1108/JOCM-06-2017-0238

Esa, E., \& Zahari, A. (2016). Corporate social responsibility: Ownership structure, board characteristics and the mediating role of board compensation. Procedia Economic and Finance, 35, 35-43. https://doi.org/10.1016/S2212-5671(16)00007-1

Ghazali, M. (2007). Ownership structure and corporate social responsibility disclosure: Some Malaysia evidence. Corporate Governance: The International Journal of Business in Society, 7(3), 251-266. https://doi.org/10.1108/14720700710756535

Habbash, M. (2016). Corporate governance and corporate social responsibility disclosure: Evidence from Saudi Arabia. Journal of Economic and Social Development, 3(1), 87-103. https://doi.org/10.1108/SRJ-07-2015-0088

Hopkins, M. (2005). Measurement of corporate social responsibility. International Journal of Management and Decision Marketing, 6(3), 213-231. https://doi.org/10.1504/IJMDM.2005.006549

Hu, Y., Zhu, Y., \& Hu, Y. (2016). Does ownership type matter for corporate social responsibility disclosure: Evidence from China. Global Conference on Business and Finance Proceeding, 11(1), 183-197.

Isa, M., \& Muhammad, S. (2015). The impact of board characteristics on corporate social responsibility disclosure: evidence from Nigeria food product firms. International Journal of Management Science and Business Administration, 1(12), 34-45. https://doi.org/10.18775/ijmsba.1849-5664-5419.2014.112.1004

Jamali, D., \& Mirshak, R. (2007). Corporate social responsibility (CSR): Theory and practice in a developing country context. Journal of Business Ethics, 72, 243-262. https://doi.org/10.1007/s10551-006-9168-4

James, H. (1999). Owner as manager: Extended horizons and the family firm. International Journal of the Economics of Business, 6(1), 41-55. https://doi.org/10.1080/13571519984304

Jensen, M., \& Meckling, W. (1976). Theory of the firm: Managerial behavior, agency costs and ownership structure. Journal of Financial Economics, 3, 305-360. https://doi.org/10.1016/0304-405X(76)90026-X 
Jizi, M., Salama, A., Dixon, R., \& Stratling, R. (2104). Corporate governance and corporate social responsibility disclosure: evidence from the US banking sector. Journal of Business Ethics, 125(4), 601-615. https://doi.org/10.1007/s10551-013-1929-2

Khan, A., Muttakin, M., \& Siddiqui, J. (2012). Corporate governance and corporate social responsibility disclosures: Evidence from an emerging economy. Journal of Business Ethics, 114(2), 207-223. https://doi.org/10.1007/s10551-012-1336-0

La Porta, R., Lopez-de-Silanes, F., \& Shleifer, A. (1999). Corporate ownership around the world. Journal of Finance, 54, 471-517. https://doi.org/10.1111/0022-1082.00115

Lamb, N., Butler, F., \& Roundy, P. (2017). Family firms and corporate social responsibility: Exploring concerns. Journal of Strategy and Management, 10(4), 469-487. https://doi.org/10.1108/JSMA-02-2016-0010

Lau, C., Lu, Y., \& Liang, Q. (2016). Corporate social responsibility in China: A corporate governance approach. Journal of Business Ethics, 136(1), 351-383. https://doi.org/10.1007/s10551-014-2513-0

Liu, M., Shi, U., Wilson, D., \& Wu, Z. (2017). Does family involvement explain why corporate social responsibility affects earnings management? Journal of Business Research, 75, 8-16. https://doi.org/10.1016/j.jbusres.2017.02.001

Mousa, G., Desoky, A., \& Khan, G. (2018). The association between corporate governance and corporate social responsibility disclosure-Evidence from GCC countries. Academy of Accounting and Financial Studies Journal, 22(4), 1-18.

Naseem, M., Riaz, S., \& Rehman, R. (2017). Impact of board characteristics on corporate social responsibility disclosure. International J. of Business Research, 33(4), 801-810. https://doi.org/10.19030/jabr.v33i4.10001

Oh, W., Chang, Y., \& Martynov, A. (2011). The effects of ownership structure on corporate social responsibility: empirical evidence from Korea. Journal of Business Ethics, 104(2), 1-15. https://doi.org/10.1007/s10551-011-0912-z

Pham, H., \& Tran, H. (2019). Board and corporate social responsibility disclosure of multinational corporations. Multinational Business Review, 27(1), 77-98. https://doi.org/10.1108/MBR-11-2017-0084

Rees, W., \& Rodionova, T. (2015). The influence of family ownership on corporate social responsibility: An international analysis of publicly listed companies. Corporate Governance: An International Review, 23(3), 184-202. https://doi.org/10.1111/corg.12086

Reverte, C. (2009). Determinates of corporate social responsibility disclosure rations by Spanish listed firms. Journal of Business Ethics, 88(2), 351-366. https://doi.org/10.1007/s10551-008-9968-9

Said, R., Zainuddin, Y., \& Haron, H. (2009). The relationship between corporate social responsibility disclosure and corporate governance characteristics in Malaysian public listed companies. Social Responsibility Journal, 5(2), 212-226. https://doi.org/10.1108/17471110910964496

Soliman, M., \& El-Din, M. (2012). Ownership structure and corporate social responsibility (CSR): An empirical study of the listed companies in Egypt. The International Journal of Social Sciences, 5(1), 63-74. https://doi.org/10.2139/ssrn.2257816

Wood, D. (1991). Corporate social performance revisited. The Academy of Management Review, 16(4), 691-818. https://doi.org/10.5465/amr.1991.4279616

Wu, S., Lin, F., \& Wu, C. (2012). A study of Taiwanese corporate social responsibility and ownership structure. Corporate Ownership \& Control, 9(3), 111-122. https://doi.org/10.22495/cocv9i3art9

Yermack, D. (1996). Higher market valuation of companies with a small board of directors. Journal of Financial Economics, 40, 185-211. https://doi.org/10.1016/0304-405X(95)00844-5

Zhuang, Y., Chang, X., \& Lee, Y. (2018). Board composition and corporate social responsibility performance: Evidence from Chinese public firms. Sustainability, 10, 1-12. https://doi.org/10.3390/su10082752

\section{Copyrights}

Copyright for this article is retained by the author(s), with first publication rights granted to the journal.

This is an open-access article distributed under the terms and conditions of the Creative Commons Attribution license (http://creativecommons.org/licenses/by/4.0/). 